\title{
An English for Research Publication Purposes Course: Gains, Challenges, and Perceptions'
}

\section{Un curso de inglés para propósitos de publicación de investigación: avances, desafíos y percepciones}

\author{
Frank Giraldo ${ }^{2 *}$ \\ Universidad de Caldas, Colombia
}

\begin{abstract}
Academic writing for scholars wanting to publish in English has gained considerable research attention in writing circles. This article reports the findings of a case study on the gains, challenges, and perceptions about writing in English that a group of scholars had while taking an academic writing course. Two questionnaires, an indepth interview, and a teacher-researcher's journal were used for data collection. The findings emphasize gains emerging from genre-based pedagogy as a holistic approach to academic writing and usefulness of teaching strategies for writing. The study reports time, discipline, and language proficiency as challenges to overcome. Finally, the participants report differing views towards peer feedback and a predominantly positive perception of English as the language for scientific writing.
\end{abstract}

Keywords: Academic writing; English for research publication purposes; genrebased teaching; strategies for writing; peer feedback

\section{Resumen}

Existe un claro interés relacionado con la escritura académica en inglés para propósitos investigativos. Este estudio de caso caracteriza los logros, retos, y percepciones sobre escritura en inglés que un grupo de profesores investigadores tuvieron durante el desarrollo de un curso de escritura académica. Dos cuestionarios, una entrevista y un diario de campo del investigador se usaron para recoger datos. Los hallazgos sugieren

1 Received: November 7th 2018/ Accepted: May 5th 2019

2 Frank.giraldo@ucaldas.edu.co 
que la pedagogía basada en el género escrito es un enfoque holístico para aprender sobre escritura académica. Además, generan evidencia sobre lo útil que pueden ser las estrategias de escritura. El estudio también indica que el tiempo, la disciplina y la suficiencia lingüística representan retos para los participantes. Finalmente, los participantes expresan contrastes sobre la evaluación de pares y una percepción predominantemente positiva del inglés como el idioma para la escritura científica.

Palabras clave: Escritura académica; enseñanza basada en el género textual; estrategias para la escritura; inglés para propósitos de publicación investigativa; evaluación de pares.

\section{Resumo}

Existe um claro interesse relacionado com a escritura acadêmica em inglês para propósitos investigativos. Este estudo de caso caracteriza os aproveitamentos, desafios, e percepções sobre escritura em inglês que um grupo de professores pesquisadores teve durante o desenvolvimento de um curso de escritura académica. Dois questionários, uma entrevista e um diário de campo do pesquisador foram usados para coletar dados. As descobertas sugerem que a pedagogia baseada no gênero escrito é um enfoque holístico para aprender sobre escritura acadêmica. Além disso, geram evidência sobre o útil que podem ser as estratégias de escritura. $\mathrm{O}$ estudo também indica que o tempo, a disciplina e a suficiência linguística representam desafios para os participantes. Finalmente, os participantes expressam contrastes sobre a avaliação de pares e uma percepção predominantemente positiva do inglês como o idioma para a escritura científica.

Palavras chave: Escritura académica; ensino baseado no gênero textual; estratégias para a escritura; inglês para propósitos de publicação investigativa; avaliação de pares. 


\section{Introduction}

7 he English language is employed for purposes ranging from everyday communication to academic contexts. In fact, it has been documented that this language exercises great power when it comes to dissemination of knowledge through research writing, an academic endeavor on its own. Scholars have highlighted the prestige and challenges that come along with writing for publication in English (Bocanegra-Valle, 2013; Li \& Flowerdew, 2007; Lillis \& Curry, 2010), with knowledge of the language being a central challenge (Hyland, 2016b). Since English is a common language for science, scholars who lack writing skills in this language may not have the opportunity to share their expertise, an issue which has gained criticism (Hyland, 2016b; Lillis \& Curry, 2010). As the power of English for publication is self-perpetuating (Ferguson, 2007; Flowerdew, 2013), figures show that around $90 \%$ of journals publish research in this language (Lillis \& Curry, 2010). Consequently, there is a need to improve scholars' academic writing in English, as researchers have suggested (Bocanegra-Valle, 2013; Gea-Valor, Rey-Rocha, \& Moreno, 2014).

Research in English academic writing has generally focused on the experiences of students in ESL contexts; i.e. international students in American, Australian, and English universities (Green, 2013; Leki \& Carson, 1997; Morton, Storch, \& Thompson, 2015). In general, these studies indicate that such courses do help students improve linguistic and social aspects of academic writing and make them aware of the structure academic papers, e.g. research articles (henceforth RAs). Another research focus in academic writing has been the perceptions and attitudes that students have regarding the English language for academic writing (Bocanegra-Valle, 2013; Flowerdew, 2005; Morton et al., 2015). This research has indicated that researchers whose first language is not English need to develop English writing skills to disseminate their knowledge. The research also emphasizes that scholars feel disadvantaged when they do not master English for publication, but accept this language as a challenge and route to sharing their expertise (Hyland, 2016b; Pérez-Llantada, Ferguson, \& Plo, 2011). There is scarce research, however, on perceptions and learning of scholars from different disciplines while engaged in English for Research Publication Purposes (henceforth ERPP) courses and on recommendations emerging from such contexts. This paper contributes to filling that gap by showing the gains, challenges, and perceptions in English academic writing that a group of professors/researchers at a Colombian state university had while engaged in a ten-week course called Academic Writing for Publication (henceforth AWP). 


\section{Literature Review}

This literature review explores four connected areas. It discusses the relationship between English for Academic Purposes (EAP) and English for Research Publication Purposes (ERPP) and then explains how RAs are structured. Further, the paper overviews issues in teaching ERPP courses, along with relevant research studies. Lastly, the review synthesizes studies into writers' perceptions of academic writing, specifically ERPP.

\section{English for Academic Purposes and English for Research Publication Purposes}

English for Academic Purposes (EAP) teaches students the language needed to deal with tasks for academia. Thus, academic writing is a sub-type of EAP course that has received attention in research (Hyland, 2016). There is a call for these courses to be specific (e. g. planned for a particular group of people) as they respond to students' needs (Hyland, 2016; Manchon, 2013; Tribble, 2017). Thus, an ERPP course supports researchers and graduate students in their goal to publish their research and is considered a type of EAP course (Cargill, \& Burgess, 2008; Charles, 2013). Such course teaches students about RAs with a high level of specificity, a feature which is welcome in academic writing pedagogy (Atkinson, 2013; Hyland, 2016; Samraj, 2013). These courses, basically, teach students how to write research articles (Li, Flowerdew, \& Cargill, 2018).

\section{Research Articles in Academic English}

As scholars have explored, RAs are the most studied genre in academic writing. For example, the structure of introductions in RAs has led to a trend in research writing: Introductions tend to have a predictable pattern of research context, research problem, and research solution, described in depth by Swales and Feak (2004) in what they call the C.A.R.S. (Creating A Research Space) Model. Empirical RAs, in general, are divided into at least four sections (Atkinson, 2013; Tribble, 2017): Introductions, methods, results, and discussion or conclusion (also known as IMRD) and they have been the focus of few ERPP courses (for example, Flowerdew \& Wang, 2016). As authors agree, these features of academic writing in English are generalities and do not reflect RAs across fields, languages and even cultures (Flowerdew, 2013).

In an ERPP course, participants should be knowledgeable of how RAs are written in their particular fields and for particular journals (Kwan, 2010). In this regard, a pedagogy is needed that embraces how to take learners from an idea to a full-fledged RA. The next section, therefore, focuses on approaches to teaching academic writing. 


\section{Teaching ERPP Courses}

ERPP courses should be fit for specific students, under specific circumstances as Hyland (2016) argues, and be geared towards helping students to write RAs (Flowerdew \& Wang, 2016; Li et al, 2018). These authors have also suggested ideas for teaching ERPP courses. One such recommendation is the use of genre-based pedagogy, through which students become aware of the linguistic and disciplinary (content) aspects of academic writing (Manchon, 2013; Li et al, 2018) in their specific fields. Additionally, as Bhatia, Anthony, and Noguchi (2011) explain, researchers should also become aware of why authors in their fields write in a particular way. While not many studies report experiences in ERPP courses, Flowerdew and Wang (2016) suggest that for teaching RAs, one possible idea is to focus on how they are structured in their different sections, i.e. IMRD; and how language is used in them. This focus can be approached through genre-based teaching.

Research studies continuously show the usefulness of a genre-based pedagogy for academic writing, specifically when it comes to structure and grammar of papers (Cheng, 2008; Hyland, 2013), learning about how RAs are written (Flowerdew \& Wang, 2016), the opportunity to have access to exemplars, i.e. RAs written by experts (Cheng, 2008; Tribble, 2017), and the potential for writing papers in disciplinary fields (Wingate, 2012). While it has been criticized (see Jenkins, 2014, for example), genre-based pedagogy for academic writing is effective in moving learners towards texts with appropriate formats (Hyland, 2013).

Manchon (2016) argues that students in writing courses learn to write, as well as write to learn about language. Consequently, ERPP courses should help participants foster their linguistic skills. Manchon also argues that the act of writing ignites writers' metacognition given, for instance, the thinking time required for writing text. This metacognition, in turn, can help improve linguistic accuracy.

\section{Writers' Insights on Academic Writing}

This section reviews studies in which student writers express their views towards gains, challenges, and perceptions of learning to write academically in a foreign language and publishing in English.

One of the major trends in the research indicates the positive influence of genre-based pedagogies on the learning of academic writing. The studies by Cheng (2008), Crawford, Mora, and Lengeling (2016), Green (2013), Kaufhold (2015), Leki and Carson (1997), and Pearson (2003) provide evidence to suggest that analysis of disciplinary texts leads to overall awareness of academic writing conventions, including use of tenses, author stance, moves 
in sections of papers, text structure, among others. In sum, the participants in these studies learned about linguistic and rhetorical aspects of their own disciplines.

Another research focus explores the power of English for publication. In the study by Luo and Hyland (2016), the participating professors wrote in English because of the prestige and visibility this would give them. Likewise, in Bocanegra-Valle's (2013) study, the participants expressed that writing in English led to international recognition and credibility, especially in highranked journals written in this language. In a somewhat different tone, one of the participants in Crawford et al.'s (2016) case study expressed that English was imposed upon him, but he developed positive feelings towards writing in this language for his personal discipline-based publications.

Gea-Valor et al. (2014) found that the scholars thought their research writing skills in English were rather low, and found that writing the discussion section of RAs was the most challenging part of articles. Finally, the participants reported that they were most interested in writing RAs in English.

Feedback from teachers and even peers appears to be a highly valued component of academic writing courses, as student writers explain. In the studies by Morton et al. (2015) and Carvajal and Roberto (2014), students of academic writing valued feedback to improve their products, whether it came from tutors (Morton et al., 2015) or peers (Carvajal \& Roberto, 2014). Indeed, positive feedback can have such a major impact on students that it may lead to improving their confidence in academic writing, as the findings in Perpignan, Rubin, and Katznelson (2007) show. Beyond the classroom context, feedback coming from peers can help papers in their path towards publication, as Lillis and Curry (2010) show.

An interesting trend about insights from academic English writers themselves is what Perpignan et al. (2007) call byproducts in academic writing. In their study, the researchers found that whereas academic writing courses help students with their writing skills such as taking an idea to a full paper, these courses come along other benefits. According to the authors, students also become critical and thorough readers, boost their self-confidence to deal with writing tasks, and employ social skills given the interactive nature that may occur in these scenarios. Similar findings can also be found in Carvajal and Roberto (2014).

\section{Methodology}

The purpose of this study was to describe the gains, challenges, and perceptions of a group of professors-researchers in an ERPP course. This level of specificity, the expectation of emergent findings, and the use of methods 
such as questionnaires and an in-depth interview, made the research study qualitative (Silverman, 2005). Besides, the study asked participants about perceptions and attitudes towards learning how to write an RA and their engagement in an ERPP course, foci which are common in qualitative studies on academic writing (Flowerdew, 2005).

Research on academic writing has used case studies. The present study characterized the participants' gains, challenges, and perceptions as they learned to write an RA that would be potentially publishable. While case studies are limited in their scope, and therefore findings cannot be extrapolated to other contexts, this study was based on theoretical sampling (Silverman, 2005). The author explains theoretical sampling explores a particular theoretical issue (in the present case ERPP) and derives findings that may be useful to others. In fact, Flowerdew (2013) calls for case studies in academic writing, so pedagogical experiences are shared with and known to others.

\section{Context and participants}

The AWP course was offered by the languages institute of a state university in Colombia. The institute contacted the Office for Academic Affairs to ask whether an ERPP course would be welcomed at this university. The Office accepted the offer and then commissioned the institute to administer an academic writing course in English for professors and researchers wanting to publish in this language. Table 1 includes details about the AWP course.

Table 1. Features of the AWP.

\begin{tabular}{|c|c|c|}
\hline & Goal & $\begin{array}{l}\text { Support professor-researchers to write potentially publishable } \\
\text { papers in English. }\end{array}$ \\
\hline & $\begin{array}{l}\text { Length, Schedule, and } \\
\text { Language of Instruction }\end{array}$ & 10 weeks, 4 hours each week; English \\
\hline & Contents & $\begin{array}{l}\text { The C.A.R.S. model; structure and content for the } \\
\text { Introduction, Methods, Results, Discussions, and Conclusions } \\
\text { sections of RAs }\end{array}$ \\
\hline 204 & Methodology & $\begin{array}{l}\text { Genre-based analysis to read RAs across fields and find } \\
\text { writing patterns. } \\
\text { Writing strategies: Reading matrix and an outlining. } \\
\text { Peer feedback tasks based on checklists co-constructed by } \\
\text { participants. }\end{array}$ \\
\hline & Tasks & $\begin{array}{l}\text { Participants wrote and revised these sections of their RA: } \\
\text { Introduction, Methods, Results, Discussion, Conclusions }\end{array}$ \\
\hline
\end{tabular}


Eight scholars participated in the AWP course. Seven of the participants were professors and researchers at such university; one of them worked as the director of an important outreach department at the same university. Table 2 shows details about the participants in this study, including publication history and field and research focus for their papers. All names in the table are pseudonyms.

Table 2. Relevant Information on Participants in the AWP Course

\begin{tabular}{|l|l|l|l|}
\hline \multicolumn{1}{|c|}{ Pseudonym } & \multicolumn{1}{|c|}{$\begin{array}{c}\text { Publications } \\
\text { before Course }\end{array}$} & \multicolumn{1}{|c|}{ Field } & $\begin{array}{l}\text { Focus of Research } \\
\text { Paper }\end{array}$ \\
\hline $\begin{array}{l}\text { Patty } \\
\text { (Professor and } \\
\text { researcher) }\end{array}$ & Five in English & Animal physiology & $\begin{array}{l}\text { Animal } \\
\text { Immunology } \\
\text { Angelfish }\end{array}$ \\
\hline $\begin{array}{l}\text { Global Mind } \\
\text { (Administrative } \\
\text { staff) }\end{array}$ & None & $\begin{array}{l}\text { Internationalization } \\
\text { of higher education }\end{array}$ & Interculturality \\
\hline $\begin{array}{l}\text { Rumi } \\
\text { (Professor) }\end{array}$ & $\begin{array}{l}\text { Three in Spanish } \\
\text { None in English }\end{array}$ & Math & Irrational Numbers \\
\hline $\begin{array}{l}\text { Darcy } \\
\text { (Professor and } \\
\text { researcher) }\end{array}$ & $\begin{array}{l}\text { One in English } \\
\text { One in Spanish }\end{array}$ & Transportation & $\begin{array}{l}\text { Real-Time Traffic } \\
\text { Simulations }\end{array}$ \\
\hline $\begin{array}{l}\text { George } \\
\text { (Professor) }\end{array}$ & $\begin{array}{l}\text { Four in Spanish } \\
\text { None in English }\end{array}$ & $\begin{array}{l}\text { Human Factors and } \\
\text { Ergonomics }\end{array}$ & Human Fatigue \\
\hline $\begin{array}{l}\text { Sirius } \\
\text { (Researcher) }\end{array}$ & $\begin{array}{l}\text { Four in Spanish } \\
\text { One in English }\end{array}$ & $\begin{array}{l}\text { Social } \\
\text { Transportation }\end{array}$ & $\begin{array}{l}\text { Equity, Social } \\
\text { Exclusion, and } \\
\text { Well-being }\end{array}$ \\
\hline $\begin{array}{l}\text { Bill } \\
\text { (Professor and } \\
\text { researcher) }\end{array}$ & $\begin{array}{l}\text { Four in Spanish } \\
\text { One in English }\end{array}$ & $\begin{array}{l}\text { Renewable } \\
\text { Energies } \\
\text { Electrical } \\
\text { Engineering }\end{array}$ & Microgrids \\
\hline $\begin{array}{l}\text { Kalman } \\
\text { (Professor and } \\
\text { coordinator of a } \\
\text { research group) }\end{array}$ & $\begin{array}{l}\text { One in Spanish } \\
\text { One in English }\end{array}$ & $\begin{array}{l}\text { High Performance } \\
\text { Computing and } \\
\text { Modelling }\end{array}$ & Cardiac Modelling \\
\hline
\end{tabular}


Before the start of the course, the participants were asked to show proof of general proficiency in English, B2 in the Common European Framework (Council of Europe, 2001). For writing, they took a diagnostic test in which they wrote an argumentative essay to be in favor of or against lecturing in university lessons. For this test, they had to read two articles, synthesize information, and defend their position. In general, the eight participants could comfortably communicate in English but their academic writing skills needed improvement. Thus, they were welcome in the course.

Finally, the other participant in this research study was the course instructor, as a participant observer who provided insights through a researcher's journal.

\section{Data Collection Instruments}

Questionnaires and interviews were used in this study to collect data on the development of academic writing (Flowerdew, 2005; Lillis \& Curry, 2010). The first questionnaire, administered during week five of the course, asked whether participants were learning particular aspects of academic writing, research writing in their fields, and writing strategies. A second questionnaire was used to confirm gains, challenges, and/or perceptions in the course; this questionnaire had the same items as questionnaire one but with a slight change in wording: Questionnaire one asked about what participants were learning and two about what they learned. Also, this second questionnaire included a selfassessment exercise and an extra question: What do you think was the biggest lesson you had in the AWP course? The syllabus, written in Spanish, was sent to all professors at the university where the study took place, before the course started. Then, in the self-assessment, the items were copied verbatim so that participants could resort to Spanish (their L1) and not worry about reading comprehension issues in English.

The questionnaire was piloted with two academic writing instructors at the language institute of the university where the study took place. They commented on the wording of the items in Spanish so overly technical language was not present. Additionally, they suggested that participants should have the chance to ask questions, in case they did not understand what to do. See the appendix for the complete second questionnaire. No statistical calculations were conducted, given that this was a case study with few participants: Statistical significance to suggest interpretations about populations was not the purpose of the study.

An in-depth interview was conducted individually with all participants one week after the course ended. Interview questions included reasons for the participants to enroll in the course; and gains, challenges, and perceptions while 
engaged in it. For the interview, participants could resort to either English or Spanish, whichever they would feel more comfortable using. This is why some extracts in the findings are written in Spanish and translated into English.

To substantiate findings, a third instrument was used: a teacherresearcher's journal. There were ten journal entries, with addenda for particular reflections (e.g. how genre-based teaching led to awareness of how authors synthesize in research papers). The journal entries explored the gains and challenges that the participants had in the AWP, as seen from the perceptions of the teacher-researcher. The journal elicited reflection through simple prompts: What went well and why? What did not go so well and why? What lessons (conclusions) can I derive from this particular lesson?

\section{Data Analysis}

Grounded theory was used for this study. This approach has three stages (Glaser \& Strauss, 1967) for data analysis. Open codings refer to trends in the data that can be classified as they emerge. A second level is axial codings, whereby researchers look for patterns and group open codings. Finally, selective codings group axials and derive final categories that lead to the findings. To illustrate, two open codings were Positive View of English and English for Publication; these codings were grouped in an axial coding called Perceptions towards English. Finally, this axial and others were subsumed under English as the Language for Publication, a selective coding for the last level of data analysis. Data analysis was continuous to reiterate the meanings behind participants' answers (Johnson, 1992).

\section{Results and discussion}

The results from this study include the gains, challenges, and perceptions the participants had while in the AWP. Gains related to academic writing structure, careful reading, language awareness, and strategies for writing. The participants perceived language proficiency, time, and discipline as challenges for academic writing. Lastly, this report includes perceptions about the English language for publication and the role of feedback in academic writing courses.

\section{Structures in English for Publication}

A prominent gain the participants highlighted was the realization that academic writing for research publication involves discernable structures. The data samples show that participants learned the general structure for paragraphs in English, and more specifically and emphatically, the C.A.R.S. model for 
writing introductions. The data highlights that the course raised awareness of what it means, structurally, to write academically in the English language. Regarding structure, Sirius (interview) explains: "I learnt the C.A.R.S. model as I told you, eh, I think was the most revealing thing for me during the course because it gave me a very structural way of, of developing an introduction." Likewise, in questionnaire two, Darcy states that, in terms of the structure of academic articles, he learnt "The overview to go from general to specific in the paragraph, and the C.A.R.S. model'. Finally, the following entry from the researcher's journal reiterates learning related to structures for writing:

Teaching the structure of paragraphs in English seems to be eye-opening for these participants, and it should be (...) a crucial element in courses for writing RAs; similarly, the C.A.R.S. model seemed to be a first-timer for these students, and it helped them to find a way to write the introduction.

The sample data above seem to signal that, before the course, the participants did not have these structures in English, which may have led them to such a gain in writing. Other studies (Cheng, 2008; Hyland, 2013) report that academic writing courses do help students become aware of the moves needed to write RAs. The data above also shed light on the pertinence and usefulness of including the C.A.R.S model (Swales \& Feak, 2004) for ERPP courses (Flowerdew \& Wang, 2016). Allusion to this model was frequent in the data, and further signals that the participants did not know it.

\section{The Role of Reading in ERPP Courses}

Another reported gain was the effective use of reading for approaching the research articles participants explored in the course. The following data show that the participants noticed that reading made them aware of not only the aforementioned rhetorical structures in English, but also linguistic aspects and journal requirements. For example, in questionnaire one, Bill stated that "Reading matrices are very useful. I have improved the ability to analyze other articles (it's easier to find how authors signal gaps and authors'contributions) and identify the possibility to provide new contributions." Thus, the data samples appear to recognize the wholesome experience that a genre-based pedagogy to academic writing implies. In the interview extract below, Rumi commented on the impact of reading articles carefully:

If I look at the journals in my area, I start to see and understand article structures, how they focus their introduction, how they present their experiments, how they present the discussion, and how they, let's say, finish and conclude; that has been very important.

This journal entry explored how genre analysis appeared to be an enriching activity in the course. 
Genre analysis has consolidated as a fruitful approach to the analysis of RAs; participants benefited from looking at sample papers and find trends in synthesis, which they also used for papers in their own fields. For example, type of synthesis, number of authors in synthesis, and citation style.

This information aligns with literature related to a genre-based pedagogy for academic writing. Similar to this study, participants in Cheng (2008) and Hyland (2013) became aware of structure and language of academic papers. Besides, the study by Pearson (2003) showed participants learned details about citation styles, a result that also emerged in the present study.

Also, reading led participants to notice language patterns emerging from research articles. The sample data below indicate that participants identified linguistic items such as tenses and their uses; besides, through reading, the participants realized how important it is to hedge when writing discussions in research papers. In this interview sample, George comments on learning about grammar tenses: "One starts to write the article and can start talking in present, then goes to past, then future and goes back to past within the same area in the structure, without having changed." Similarly, in questionnaire two, Darcy stated that he learned "the importance of tenses to write each part of the document, and to make the discussion through hedging."

Hyland (2016) has discussed the need to address hedging in academic writing courses. The findings in this study support Hyland's argument and suggest that such a topic may make research writers aware of their role when reporting their scholarly work. Overall, the language-related results support Manchon's (2016) contention that academic writing courses not only target learning about writing but also learning about language.

\section{Strategies for Academic Writing}

A last gain for the participants involved strategies for academic writing. Specifically, the participants argued that outlining and a reading matrix helped them approach the task of writing their RAs. The data show the variety of uses that the participants gave to these two strategies. In questionnaire two, Global Mind stated that she "learnt that the outline is a powerful tool if we use it and do a very reflective work to refine it." In questionnaire one, she mentioned that she learnt that "matrix is a tool that helps me to read articles with more precision and focus. " In his interview, Darcy explained his approach to outlining.

I start to know make an outline to write anything no matter if is to write academic paper or an e-mail... it's is so important these kind of tools I start to feel comfortable because I have really really effective tools...to achieve my goals. 
Strategies for academic writing are reported in the literature. For example, Kwan (2010) implies that strategies should be part of efforts to support research writing; the present study capitalizes on that idea by means of outlining and reading matrices as writing strategies. In Green (2013), outlining was a key component for one of the participants to advance her academic writing endeavors. As for reading as a strategy to improve writing, Cheng (2008) highlights the usefulness of reading to raise awareness of academic writing.

\section{Byproducts in Academic Writing}

Perpignan et al. (2007) state that byproducts (e.g. self-confidence) in academic writing courses are gains that do not necessarily include skills directly related to writing. In the present study, confidence emerged as a byproduct of the AWP course. The participants reported in the interview that their confidence increased thanks to being engaged in the course. Kalman explored the issue of confidence for writing:

There is more confidence because there are more tools to achieve at least a well written publication; more confidence generates at the time to send more papers... it is confidence for what one is writing... I already know that I am writing better, that I have better structure, and that I am defining the gap well.

Similar to the present study, the studies by Perpignan et al. (2007) and Carvajal and Roberto (2014) also report an increase in confidence for academic writing among course participants. Therefore, that writers increase their selfconfidence seems to be a trend in the literature on learning about academic writing and may imply that, at the very least, academic writing courses can empower students for the task of writing.

\section{Challenges in an ERPP Course}

The participants stated that overall language proficiency and the lack of time and discipline may be problematic for academic writing. The first challenge, particularly, involves language proficiency, which is needed to be engaged in an academic writing course, as Patty explains in her interview: "It is a challenge to receive class in English. Expressing myself in English is still complicated for me, and despite being able to write, I find it difficult to understand and speak." When asked about challenges not related to writing, Global Mind stated in questionnaire one that a challenge was "the little time I can devote to read and write with real disposition and availability (lack of discipline???)." 
Similarly, the literature has reported challenges that students have for academic writing. Luo and Hyland (2016), for instance, state that writing in English is a challenge on its own. In Morton et al. (2015), one of the participants found it challenging to build her own writing identity. In the present study, it must be noted that these participants felt the need to develop their overall English skills; this perception is consonant with overall literature in academic writing, with scholars (Flowerdew, 2013; Lillis \& Curry, 2010) arguing that non-English researchers need strong skills in this language to interact in the scientific arena of their fields. As for time and discipline, the participants in the present study were researchers and professors or administrative staff at the university where they work, which may exercise a burden on their writing agendas.

\section{Perceptions about English and Feedback in this ERPP Course}

A last set of results in this study are perceptions the participants had towards being in the AWP course. All participants emphasized the role of English as a language for communicating science. Additionally, they had mixed perceptions about the role of peer-feedback in the AWP course. The interview data show that all the participants view English as the go-to language for publication, regarding it as useful for communication with peers from around the world. For example, in his interview, Sirius stated the following.

I think it's the way to go. It doesn't, for me it doesn't make sense to write scientifically in Spanish. Eh, why? Because, well, science is written in English. I think that English eh puts eh a standard to the way scienti... science is written. They say everybody are going to write in English so you have to write in English now. Eh you can communicate your research, your interests with a guy in Russia or with a guy in China.

In her interview, Patty shared similar feelings to Sirius': "English is the perfect language to write science."

In conclusion, it seems that, for the participants, English is the de facto lingua franca for scientific writing, given its usefulness for communicating research in their fields. Particularly, readers may remember that Patty has written five articles in English, which could suggest that she is used to writing in this language -or perhaps her discipline encourages this fact. It has been remarked that English is powerful for communication, and it is a goal for scholars wanting to publish in this language (Bocanegra-Valle, 2013; PérezLlantada et al, 2011). The same trend seems to underlie the present study. Participants had it as a goal to write academically in English to have potentially publishable work. It is worth noticing that seven of the participants published in English, which may ignite positive attitudes towards the language. 
Regarding the role of peer feedback in the course, participants had differing views. For example, George argued that peer feedback was useful to analyze his own writing. In the interview, he shared the following insight.

When I read what a classmate had done, I gave it an interpretation ... and then he'd tell me: 'No, what I mean was this.' So I found that there was no clarity... so that'd make us see that we had to think about the reader.

Conversely, Sirius mentioned: "I honestly think that you are not in the position to give feedback. I gave feedback only on the positive... and he didn't give me feedback. Maybe he felt the same." In the teacher's journal, reflections on feedback were positive: "Peer feedback in these courses may lead to an awareness towards being clear when writing, even if people from other fields read one's paper."

The participants viewed peer feedback mainly positively in the course. In the study by Carvajal and Roberto (2014), participants benefitted from receiving feedback from partners. However, the data in the present study also suggest a caution for the place of feedback in academic writing courses, specifically when writers come from different fields. It is this fact perhaps what makes peer feedback a challenge: In an ERPP course with researchers from different fields, they may feel they do not have the authority to comment on others' work. This is interesting, as students were asked to focus on the moves for their articles, not on their content, as this journal entry explains: "Even with students coming from different fields, peer feedback may be useful as long as it is guided by frameworks such as the CARS model".

\section{Conclusions and recommendations}

Few case studies of ERPP courses are reported in the literature, which is a gap this present case study seeks to start to fill. The present study reports that, among the main gains from being engaged in the AWP course, the participants highlighted learning about rhetorical structures for writing in English. Other gains included the power of reading articles and learning about language structures by this means. Finally, a prominent gain in the study was the use of the two strategies taught for writing: A reading matrix and outlining. This may mean there is a space for explicit attention to writing strategies in ERPP courses. Furthermore, the participants reported time, discipline, and language proficiency as challenges to surpass in ERPP. Finally, the participants viewed English as an appropriate language for the publication process and shared differing views on peer feedback.

While a limitation of the present research is that it is a case study in a context with unique researchers, three recommendations may prove useful for other places where these context-sensitive ERPP courses may be designed. 
First and foremost, a genre-based pedagogy is fully supported in this study. Teachers may want to explore such approach for teaching (academic) writing; for instance, they may engage students in close reading of texts through which they can identify rhetorical and language patterns (as shown in Flowerdew \& Wang, 2016); in the present case, empirical RAs were useful to identify patterns such as how sentences are structured in their discussion section, or linguistic choices such as the accurate use of tenses. Second, students should be taught strategies for writing. In this study, outlining and a reading matrix were new to the participants, who fully embraced the strategies and made them their own. Along with skills in genre analysis, specific strategies help writers become more confident-as the findings here suggest-to approach the research writing task. Finally, peer feedback does have a place in academic writing courses but teachers must be aware that in contexts where students are writing widely different papers, there may be some resistance due to professional factors (e.g. face-keeping). In such case, teachers may want to direct feedback to, for example, how students are transitioning in paragraphs or hedging: Peer feedback could focus more on structure and language, rather than content. Thus, the role of peer feedback in an ERPP course is a recommended research path, especially when it is used with students coming from different disciplines. 


\section{References}

Atkinson, D. (2013). Research articles in English for specific purposes. In C. Chapelle

(Ed.), The Encyclopedia of Applied Linguistics, 1-6. Chichester (UK): John Wiley and Sons.

Bhatia, V., Anthony, L., \& Noguchi, J. (2011). ESP in the 21st century: ESP theory and application today. Proceedings of the JACET 50th Commemorative International Convention, 143-150.

Bocanegra-Valle, A. (2013). The perceived value of English for academic publishing among ESP multilingual scholars in Europe. Journal of English for Specific Purposes at Tertiary Level, 1(1), 5-25.

Cargill, M., \& Burgess, S. (2008). Introduction to the special issue: English for research publication purposes. Journal of English for Academic Purposes, $7(2), 75-76$.

Carvajal, N. \& Roberto, E. (2014). Collaborative work as an alternative for writing research articles. PROFILE: Issues in Teachers' Professional Development, (16)1, 119-136

Cheng, A. (2008). Analyzing genre exemplars in preparation for writing: The case of an L2 graduate student in the ESP genre-based instructional framework of academic literacy. Applied Linguistics, 29(1), 50-71.

Council of Europe (2001). Common European framework of reference for languages: Learning, teaching, and assessment. Cambridge, UK: Cambridge University Press.

Crawford, T., Mora, I., \& Lengeling, M. (2016). Struggling authorial identity of second language university academic writers in Mexico. PROFILE: Issues in Teachers' Professional Development, (18)1, 115-127.

Ferguson, G. (2007). The global spread of English, scientific communication and ESP:Questions of equity, access and domain loss. Ibérica, 13, 7-38.

Flowerdew, J. (2005). A multimethod approach to research into processes of scholarly writing for publication. In P. K. Matsuda and T. Silva (Eds.), Second Language Writing Research: Perspectives on the Process of Knowledge Construction, 65-77. Mahwah, NJ: Lawrence Erlbaum.

Flowerdew, J. (2013). English for Research Publication Purposes. In B. Paltridge \& S. Starfield (Eds.), The handbook of English for specific purposes: First edition, 301-321. Boston, USA: Wiley-Blackwell. 
Flowerdew, J. \& Wang, S. (2016). Teaching English for research publication purposes with a focus on genre, register, textual mentors and language reuse: a case study. In J. Flowerdew \& T. Costley (Eds.), Discipline-Specific Writing: Theory into Practice, 144-161. London, UK: Routledge.

Gea-Valor, M., Rey-Rocha, J., \& Moreno, A. (2014). Publishing research in the international context: An analysis of Spanish scholars' academic writing needs in the social sciences. English for Specific Purposes, 36, 47-59.

Glaser, B. J. \& Strauss, A. L. (1967). The discovery of grounded theory: Strategies forqualitative research. New Jersey: Aldine Transaction.

Green, S. (2013). Novice ESL writers: A longitudinal case-study of the situated academic writing processes of three undergraduates in a TESOL context. Journal of English for Academic Purposes, (12)3, 180-191.

Hyland, K. (2009). English for professional academic purposes: Writing for scholarly publication. In Belcher, D. (Ed.), English for Specific Purposes in Theory and Practice, 83-105. Ann Arbor, MI: University of Michigan Press.

Hyland, K. (2013). Teaching language for academic purposes. In C. Chapelle (Ed.), The Encyclopedia of Applied Linguistics, 1-4. Chicester (UK): John Wiley and Sons.

Hyland, K. (2016). General and specific EAP. In K. Hyland \& P. Shaw (Eds.), The Routledge Handbook of English for Academic Purposes, 17-29. New York: Routledge.

Hyland, K. (2016b). Academic publishing and the myth of linguistic injustice. Journal of Second Language Writing, 31, 58-69.

Jenkins. J. (2014). English as a lingua franca in the international university: The politics of academic English language policy. Abingdon: Routledge.

Johnson, D. (1992). Approaches to research in second language learning. New York: Longman.

Kaufhold, K. (2015). Conventions in postgraduate academic writing: European students' negotiations of prior writing experience at an English-speaking university. Journal of English for Academic Purposes, 20, 125-134.

Kwan, B. S. C. (2010). An investigation of instruction in research publishing in doctoral programs: The Hong Kong case. Higher Education, 59, 55-68.

Leki, I. \& Carson, J. (1997). "Completely different worlds": EAP and the writing experiences of ESL students in university courses. TESOL Quarterly, 31(1), 39-69.

Li, Y. \& Flowerdew, J. (2007). Shaping Chinese novice scientists' manuscripts for publication. Journal of Second Language Writing, 16, 100-117. 
Li, Y., Flowerdew, J., \& Cargill, M. (2018). Teaching English for research publication purposes to science students in China: A case study of an experienced teacher in the classroom. Journal of English for Academic Purposes, 35, 116-129.

Lillis, T. \& Curry, M. (2010). Academic writing in a global context: the politics and practices of publishing in English. New York: Routledge.

Luo, N. \& Hyland, K. (2016). Chinese academics writing for publication: English teachers as text mediators. Journal of Second Language Writing, 33, 43-55.

Manchon, R. (2013). Teaching writing. In C. Chapelle (Ed.), The Encyclopedia of Applied Linguistics, 1-4.

Manchon, R. (2016). Language and L2 writing: learning to write and writing to learn in academic contexts. In K. Hyland \& P. Shaw (Eds.), The Routledge Handbook of English for Academic Purposes, 139-151. New York: Routledge.

Morton, J., Storch, N., \& Thompson, C. (2015). What our students tell us: Perceptions of three multilingual students on their academic writing in first year. Journal of Second Language Writing, 30, 1-13.

Myskow, G. \& Gordon, K. (2009). A focus on purpose: using a genre approach in an EFL writing class. ELT Journal, 64(3), 283-292.

Pearson, C. (2003). Multiple uses of applied linguistics literature in a multidisciplinary graduate EAP class. ELT Journal, 57(1), 43-50.

Pérez-Llantada, C. Ferguson, G., \& Plo, R. (2011). "You don't say what you know, only what you can": The perceptions and practices of senior Spanish academics regarding research dissemination in English. English for Specific Purposes, 30, 18-30.

Perpignan, H., Rubin, B., \& Katznelson, H. (2007). 'By-products': The added value of academic writing instruction for higher education. Journal of English for Academic Purposes, 6(2), 163-181.

Samraj, B. (2013). Research articles. In K. Hyland \& P. Shaw (Eds.), The Routledge Handbook of English for Academic Purposes, 403-415. New York: Routledge.

Silverman, D. (2005). Doing qualitative research. London, UK: Sage Publications.

Swales, J. \& Feak, C. (2004). Academic writing for graduate students: Essential tasks and Skills. Ann Arbor: University of Michigan Press. 
Tribble, C. (2017). ELFA vs. Genre: A new paradigm war in EAP writing instruction? Journal of English for Academic Purposes, 25, 30-44.

Wingate, U. (2012). Using academic literacies and genre-based models for academic writing instruction: A 'literacy' journey. Journal of English for Academic Purposes, (11)1, 26-37.

\section{Author}

*Frank Giraldo is a professor in the Foreign Languages Department at Universidad de Caldas, Colombia. His interests include language testing and assessment, language assessment literacy, language curriculum development, and language teacher professional development.

ORCID: https://orcid.org/0000-0001-5221-8245 


\section{Appendix}

\section{Second Questionnaire}

Dear professor, please answer the questions below based on your experience in the Academic Writing for Publication Course. You can answer the questions in English or Spanish.

1. In the Academic Writing for Publication course, did you learn anything about...

a. academic writing in general? If yes, what? If not, why?

b. analysis of research articles? If yes, what? If not, why?

c. research writing in your own field? If yes, what? If not, why?

d. writing strategies? If yes, what? If not, why?

e. structure of academic and research articles? If yes, what? If not, why?

2. Anything else you learned about academic writing?

3. In the Academic Writing for Publication course, have you had any challenges or difficulties related to writing? If so, please describe them.

4. Have you had other types of challenges? If so, please describe them.

5. Is there anything you need to improve in terms of academic writing? If so, please describe.

6. Look at the specific objectives/skills that were part of the course. Evaluate you whether you achieved the objective or not. Use this scale:

1: I did not achieve this objective.

2: I am still struggling with this objective.

3: I achieved this objective. 
Specific objectives for the AWP course (Taken from the syllabus written in Spanish and sent to all professors and researchers where study took place.)

$1 \_2 \_3$

Evaluar fuentes de información para la escritura de textos académicos y científicos; estas fuentes incluyen revistas, convocatorias para eventos, libros editados, entre otras.

$1 \_3$

Crear matrices para organizar literatura relacionada con el tema de investigación o del artículo.

$1 \_3$

Escribir un esquema exhaustivo del escrito en desarrollo.

$1 \_3$

Sintetizar fuentes de información para crear argumentos sólidos en la escritura del texto.

$1 \_3$

Entender y usar los "movimientos estructurales" en las diferentes secciones de textos

$1 \_3$

Tener prácticas éticas relacionadas con la escritura académica en inglés, por ejemplo citas efectivas, confiabilidad de fuentes de información, entre otras.

7. What do you think was the biggest lesson you had in the AWP course?

8. What recommendations do you have for the course?

Thank you! 